the prevention of war. What will the Day of the Chemist bring forward as his contribution to war's prevention? And yet despite the possession by the German nation of a highly honored body of the world's greatest scientists the scourge came and none could stay it. Something more then is required than simple devotion to scientific truth. Is it "reasonableness?" In other words, that spirit of mind which is not allied to partisanship--the balanced, considerate and open mind. When that shall be the recognized mental equipment of every scientific man, then shall dawn the True Day of the Chemist.

200 FIFTh AVENUE, NEW YORE CiTY

\section{NITROGEN AND NITRATES FROM BITUMINOUS COAL ${ }^{1}$}

By C. G. ATWATER

Received September 23, 1916

Every few years a wave of nitrogenous famine seems to sweep over the daily press, arousing more or less interest and apprehension on the part of the public. Coincident with these waves, discoveries which remove the danger of famine and therefore deliver posterity from the prospect of perishing of starvation, are brought to public view.

Some eight or nine years ago Sir William Crookes sounded a "note of alarm" and our deliverance by the recovery of atmospheric nitrogen through the electric arc was predicted. A few years later commercial cultures of nitrogen-fixing bacteria were discovered and their beneficial activities were greeted with more or less journalistic and public enthusiasm. The New York Tribune, commenting editorially on the appearance of electrolytic fixation and of the nitrogen-fixing bacteria at that time, proclaimed its entire willingness to credit the inventors of either process with the preservation of our descendants from death by hunger, but admitted its inability to give both credit for the same beneficent work.

I have not seen in the public prints any wide-spread announcement of the fact that the recovery of nitrogen from bituminous coal is destined to save future generations from starvation, but in view of the fact that this process has always had and still has as great a promise as either of the others and is much closer to our ordinary manufacturing operations and industrial organization, I feel that such a proclamation may be expected at any moment. While there is an attractive touch of romance in the idea of converting the atmosphere into food, even though somewhat overworked of late, it must be remembered that even in the legend, the rainbow was in the air, while the pot of gold had to be dug out of the ground at its foot.

These circumstances furnish me with some shadow of excuse, at least, for this paper. Additional color is given to this excuse by the fact that the immediate demand of nitrogen for producing food for the preservation of life is supplemented by a dire need for it in the production of explosives to be used in quite the opposite direction. It might be interesting, but would probably be quite useless, to speculate as to whether these two needs could not be so manipulated as ultimately to neutralize each other in the outcome.

\section{AMMONIA FROM BITUMINOUS COAI}

In speaking of the potential amounts of ammonia recoverable from bituminous coal, as has been done for years past in the public prints, it has been the habit to limit such speculation to the amount of coal actually made into coke. There were at least two good reasons for this, one being that this coal was already being subjected to the process of destructive distillation and hence was commercially eligible for treatment by the byproduct recovery process. A second was that the amount of ammonia recoverable from the coking operation was until recently so far in advance of the amount actually being recovered, the ratio being about 4 to I, that any argument for

I Paper read before the American Chemical Society, New York City, September 25-30, 1916 conservation or contrast with Furopean practice could be sufficiently enforced with this simple illustration without going further afield. Such statements, so far as I have been guilty of them, erred only on the conservative side. They limited themselves to the replacement of beehive coke, used almost exclusively in iron smelting, with by-product coke. They took no account of the extremely probable increase in the iron industry and they passed by, in rather a cursory fashion, the immense production that would ensue if even a moiety of our ordinary fuel consumption were conducted with by-product recovery. A little closer examination of the actual conditions will show how important these omissions were.

In order to get the data in proper sequence, I will first state the present figures. The ammonium sulfate production in the United States for the year I9I5 is estimated at 220,000 net tons, figuring all forms of ammonia as sulfate. The largest amount of coal made into coke in any one year, as reported to date, including beehive, by-product and gas-house coke, was in I913, and amounted to over 73 million tons. This should have yielded over 700,000 tons of ammonium sulfate. In other words, the maximum recovery is a little less than one-third of the maximum amount possible. It is highly probable, however, that the year I9I6 will increase the total figures, though it may not change their ratio. The beehive coke production for the past half year, if maintained, will give the largest year on record, and the same is true of the by-product coke output. An increase of 25,000 to 50,000 tons of ammonium sulfate for the year is considered probable. There are estimated to be 2,600 new by-product coke-ovens actually under construction, and I, Ioo more that have been definitely decided upon. These will add about $15,000,000$ tons of by-product coke to the annual capacity when completed, so that within two years an output of 375,000 to 400,000 tons of ammonium sulfate per year is quite possible if business conditions favor complete operations.

The output of bituminous coal for the year I 9 I 5 was 438 ,550,000 tons and the Geological Survey's estimate for I9I6 is 500 million tons. If we figure a recovery of I per cent in ammonium sulfate this would amount to 5 million tons per annum. All of this ammonia is recoverable, and all but the modicum recovered is now wasted. The first objection to this statement that will occur is, of course, the difficulty of recovering byproducts from the simple furnaces in which most of this coal is consumed. These difficulties are by no means so great as has been popularly accepted and a notable amount of progress has recently been made along the line of substituting methods of fuel treatment that permit of ammonia recovery.

In the first place a great deal of coke is now being used in place of anthracite coal. The latter has constantly risen in price and its production is decreasing. In many districts of the Middle West, coke has taken its place as a smokeless fuel. There are a number of coke-oven plants which regularly turn a respectable portion of their output into domestic coke and this business is steadily increasing. Domestic coke is regularly distributed from the coke plants at Chicago, Ill., Milwaukee, Wis., Duluth, Minn., St. Louis, Mo., Muncie and Indianapolis, Ind., Hamilton, Ohio, Detroit, Mich., Glassport, Pa., Geneva, N. Y., Everett, Mass., Camden, N. J., and is obtainable in many other cities. Some domestic coke will also be supplied to the local market from the new plant now building near Newark, N. J. These conditions are emphasized by the fact that there is no prospect of any diminution in the price of anthracite, nor is it to be expected that the present burners of smokeless fuel will ever return to the former smoky and undesirable conditions.

An additional impulse in this direction is the increasing domestic and industrial consumption of gas. Large areas of the Middle West have been accustomed to natural gas at a low price. The supply seems to be finally on the wane and it is only 
a question of time when this territory will have to be supplied with artificial coal-gas, which will necessarily be made with the recovery of by-products, including ammonia, or for industrial uses, with producer gas, which may well be made with byproduct recovery. Some years ago much was expected in the way of ammonia recovery from bituminous coal by the agency of the Mond gas producer. The expected development in this direction did not take place. Certain drawbacks stood in the way of its wider introduction and its coadjutor in power development, the large gas engine, found difficulty in competing in cost of installation and operation with the steam turbine. Later developments in modified forms of the Mond producer, as in the I,ymn type of apparatus, have brought about the introduction and successful commercial operation of a number of stch ammonia- and power-producing plants in Great Britain and in Germany, Italy, Spain, China, and Japan as well. There is good reason to believe that progress in this country in this direction will not be much longer delayed. It must be noted in this connection that the ammonia recovery from coal treated in these producers is approximately four times as great as in the by-product coke-oven. With our accepted practice of concentrating power generation in large central stations, there is good reason for considering this development as an immediate commercial possibility.

Another reason for an increased use of ammonia from bituminous coal is the low cost of production, compared with the electrolytic or synthetic processes, when necessary transportation costs are included. The advantage that coke-oven ammonia has in this respect been stated frequently, and by various acceptable authorities, and so far as I know this has never been contradicted by anyone even approximately without bias. It therefore seems of little use to set up a man of straw in order to overturn him. Coke-oven ammonia, being recovered as a by-product of the main product, coke or gas, is produced with but minor regard as to the demand for it, hence must be sold for the best price obtainable. Therefore, in any event, the argument for it, in view of the existing coke industry and undertakings, would probably partake of the nature of a request to "Come on in, the water's fine!" Certainly a statement that ammonia could be made more cheaply on a commercial basis by resort to water-power development would hardly seem to be an adequate reason for asking the Government to lend financial aid to such an enterprise, more particularly when such a project includes the making of fertilizers in times of peace, as well as explosives in war. There are a half-dozen other good reasons why coke-ovens are our best source of ammonia, in peace or war--geographical distribution, immunity from enemy attack, speed with which new units can be erected, production of other essential materials, conservation of natural resources, I cannot stop to go into them all, more especially as they have been adequately covered elsewhere. ${ }^{1}$

TRANSFORMATION OF AMMONIA TO NITRIC ACID

The oxidation of ammonia to nitric acid is practically a new process in this country. Commercially, its prospects seem to offer little attraction, as the ordinary method of producing nitric acid by treating sodium nitrate with sulfuric acid is a less expensive one. Its principal function would be in time of war when sodium nitrate would possibly not be obtainable.

As the great resource of this country for combined nitrogen lies in the recovery of ammonia from bituminous coal, the adaptability of this form of ammonia to oxidation by the Ostwald or some other process is most important. The Ostwald process, as is well known, depends upon the action of a catalyst

1 See paper "Ammonium Sulfate as a Source of Combined Nitrogen," by J. W. Turrentine, This Journal, 8 (1916), 584; H. Koppers Company, Pittsburgh, Pa., Pamphlet, May, 1916; "Position of Gas Industry in the Nation's Scheme for Preparedness," by W. H. Gartley, Gas Institute News, 5 (1916), 302; paper "Sources of Nitrogen Compounds in the United States," by Chester G. Gilbert, Smithsonian Institution, June, 1916. on a mixture of ammonia and air, or air and oxygen, such catalytic action being more or less subject to derangement or poisoning by certain impurities. Granted that the Ostwald process is capable of producing nitric acid from ammonia in large quantities, which in view of the present European experience we may safely assume, the question resolves itself into an investigation of the effect of the impurities and the process of their removal if necessary.

That the impurities in coke-oven ammonia can be successfully removed so as to deliver a gas that is to all intents and purposes pure, has been amply demonstrated. This is regularly done in the manufacture of anhydrous ammonia, aqua ammonia, and ammonia for the production of pure ammonium salts. The methods employed, it is not necessary here to describe. It is probably possible to modify these methods for the purification of ammonia for oxidation on a scale of, say, one hundred tons per day, at a reasonable cost, and what modifications, if any, are permissible in order to lessen this cost without interfering with the practical operation of the catalyst, are problems that can be solved only by diligent experimentation on a laboratory and on a factory scale. In addition to the successful work which has unquestionably been done abroad, such investigations have been recently undertaken by several different agencies in this country and considerable progress has been made. From one source of unquestioned authority, I am authorized to make the following statement:

"Independent laboratory investigations have definitely shown that we can purify coke-oven ammonia on a commercial scale quite well enough to permit satisfactory oxidation to nitric acid. The expense of purification is well within reasonable limits, and the experiments indicate that there is no practical obstacle to the use of coke-oven ammonia for nitric acid manufacture. Definite statements on this point are withheld until an actual commercial denonstration can be made."

As further evidence of the practicability of the oxidation process, I am indebted to Mr. Lewis A. Riley, of New York City, for the following brief statement of the Ostwald process for the oxidation of coal ammonia to nitric acid:

"In the year Igoo Professor Ostwald made arrangements to carry on his experiments with the Central Station for Scientific Technical Investigations in Neubabelsberg, near Berlin, which was an Institution supported by a number of explosive works in Germany to undertake industrial investigations and work out technical processes. These experiments were under the general direction of Herr Geheimrath von Duttenhofer of the Rottweiler Explosive Works. Before the conclusion of this experimental work in the year 1903 Herr von Duttenhofer died and his successor abandoned the work in an unfinished condition.

"The Chemical Works Griesheim-Elektron next interested themselves in the matter and carried on some experimental work in which the previous apparatus from Berlin was used.

"In the summer of 1904 official tests gave only 70 per cent conversion efficiency which appeared insufficient for commercial success. This led the Griesheim Works to abandon the experiments, although immediately subsequent to these tests the cause of the low yield was discovered and remedied, it being found that the platinum contacts required more frequent chang. ing

"The process was then taken up by the Gewerkschaft des Steinkohlenbergweriss Lothringen at Gerthe, near Bochum, and in $x 906$ a small plant was put down and operated there, which gave a conversion of 85 per cent on which results the Lothringen Company decided to proceed with the building of a large plant.

"The construction of this large plant was badly handled and resulted in some unfortunate litigation, owing to the constructing engineers and manufacturers having departed from the designs and specifications in certain parts and some of the auxiliary apparatus gave considerable trouble.

"The plant was in certain respects rebuilt and although the first cost of the plant was on this account considerably higher than should have been the case, it was, nevertheless, satisfactorily completed in 1908 and since December of that year it has operated continuously.

"Sometime during the year roro the operation of this plant was carefully investigated and tested by the Nitrate Products Company, Ltd., of London, and was purchased by this com- 
pany which is understood to be closely affliated with the cyanamide interests. The purchase was made based on this investigation and tests which were stated to show a conversion efficiency of 85 per cent on the basis of ammonia to nitric acid, corresponding to the tests of the experimental plant of the Lothringen Company and on which the latter company originally accepted the process.

"The plant since beginning operations in rgo8 down to a period just preceding the present war had operated practically continuously, using coal-ammonia from the Bochum coke-ovens for the production of nitric acid. The nitric acid produced was then used for the further absorption of additional ammonia in the production of commercial ammonium nitrate which has been disposed of on the market as such. This plant and process was, therefore, developed and perfected in the use of coalammonia as the nitric acid raw material and its success on this material was thoroughly demonstrated both by the operations conducted by the original owners, the Lothringen Company, and subsequently by the Nitrate Products Company.

"A further development of this plant and process has been its application to the oxidation of cyanamide ammonia and it is understood that the second plant built for the commercial oxidation of ammonia which was located in Belgium was designed for the utilization of cyanamide-ammonia.

"Test figures on the operation of this plant for a 20-month period show 83 per cent nitric acid conversion with 97 per cent ammonia absorption.

"The ammonia oxidation process has, since Igro, been controlled by the Nitrate Products Company. It is understood that its application by this company has been restricted to the oxidation of cyanamide-ammonia although the Gerthe plant was being successfully operated on coal-ammonia up to the start of the present war."

To this statement I may add that, according to Lunge ${ }^{1}$ on the authority of the Deutsche Ammoniak-Verkaufs-Vereinigung, the sales of ammonium nitrate produced by the Ostwald process at the Lothringen plant, were as follows: $65 \mathrm{I}$ tons in $\mathrm{Ig08}$; $x, 096$ tons in $1909 ; 1,237$ tons in 1910 ; about the same in IgII. All these amounts and the subsequent production to the opening of the war are to be credited to coal-ammonia.

In conclusion I may cite the following summary, from the last edition of Lunge, which carries additional weight, coming as it does from Central Europe, where they have produced more ammonia from coal, and more from the atmosphere, and have transformed more of it into nitric acid, than in any other country:

"The synthetical production of ammonia from atmospheric nitrogen must find its limits in the impossibility of producing the requisite enormous amount of electrical energy in infinitum, whether by water-power or otherwise. As far as we can look forward, the principal source of ammonia will be always the nitrogen of coal, just as this has been the case for a long time past in the case of the comparatively small fraction of coal consumed for the manufacture of illuminating-gas, and more recently by carrying out the coking of the coal in such a way that the formerly lost by-products, ammonia and tar, are recovered. This last proceeding is sure to be more and more extended. Even the general conversion of the coal to be used for heating, into gaseous fuel, with recovery of its nitrogen in the shape of ammonia, is within visible distance."

The BarretT Company

17 BATTERY PLACE, NEW YORK CITY

\section{EARLY CHEMICAL MANUFACTURING IN PHILADELPHIA ${ }^{2}$}

By Samuel, P. Sadther
Received October 24,1916

The earliest efforts at chemical manufacturing in Philadelphia, as in other parts of the American Colonies, were undoubtedly due to the feeling of the colonists that they must free themselves from the oppressive trade regulations of the mother country. We read in the sketch of the career of one of the pioneers of Philadelphia chemical industry, the following:

"The earliest efforts of the colonists-the manufacture of coarse, woolen fabrics in I 719--so excited the jealousy of Great Britain that the English Parliament declared 'that the erecting of factories in the colonies must be discouraged at all cost,' so

1 "Coal-Tar and Ammonia," 5th ed., 1916, p. 1572.

2 Address before the Philadelphia Section of the American Chemical Society, October 19, 1916. every enterprise met with great opposition. It was not, however, until I774 that Pennsylvania became so aroused by English oppression of her industries that a convention of delegates from all the counties was held in Philadelphia. Joseph Reed was president, Jonathan B. Smith, John Benezet and Francis Johnston were secretaries. The convention earnestly enforced the strict observance of non-importation agreements and to provide against the inconvenience which might result, recommended the preservation of sheep until they were four years old, and the immediate establishment of the manufacture of woolens, salt, saltpetre, iron, nails, copper in sheets and kettles, malt liquors and gunpowder especially, 'as there existed a great necessity for the latter, particularly in the Indian trade.' The convention advised the exclusive use of home manufactured articles and urged that associations be immediately formed for the encouragement of all domestic productions."

This feeling only came to a head about the time of the beginning of the Revolutionary War. Prior to that, in the Colonial period, the production of potashes and lime, some attempts at the extraction of salt from brines, tentative efforts at the making of gunpowder, and domestic utilization of the potashes in soapboiling about comprised the chemical manufacturing industry. Of these the most important was the manufacture of potash from wood-ashes. Scharf and Westcott's "History of Philadelphia" states that in 1772 the value of the potashes manufactured in America was $£_{50}, 000$.

As before stated, the oppressive trade regulations of England acted as an impelling force in the establishment of chemical industries. Thus the exportation of powder and its materials from England was prohibited by an order of Council of October 19, I774, so that the American Colonies were made dependent on other sources for their supply.

"The Continental Congress in various ways encouraged the erection of powder mills and also the production of nitrate of potash. Congress in 1775 published a manual giving directions for making saltpetre, and about the same time the "Committee of the City and Liberties' erected a large saltpetre works on Market Street for the double purpose of making saltpetre and also to instruct such as were willing to engage in the making of this very necessary article for the powder mills.

"The manufacture of gunpowder was very extensively carried on during the Revolution in nearly all of the American Colonies. A very large proportion of this powder, however, was made in Pennsylvania. Philadelphia was among the first places in which powder mills were successfully operated.

"Early in the Revolution a public powder mill was established in or near Philadelphia by the Assembly, while Congress opened, and for some time operated, what was known as 'The Continental Powder Mill.' Congress also offered advances to such persons as would be willing to establish powder mills within 50 miles of the city of Philadelphia, and this offer was taken advantage of by many who subsequently stpplied a liberal proportion of the powder used in the Continental Army."

But to come back to the efforts of the Colonists to free themselves in other lines from dependence on the mother country, we read in the sketch of the career of Samuel Wetherill, from which we previously quoted:

"Samul Wetherill was one of the promoters and managers of the 'United Company of Pennsylvania for the establishment of American Manufactures.' He embarked his whole soul in the business, and in 1775 set up at his own dwelling house in South Alley, then called Hudson Square, now Commerce Street, a factory for jeans, fustians, everlastings and coatings (Fustian is a cloth, the warp of which is linen and the woof thick cotton; it derived its name from Fusht, a town on the Nile where it was first made). This business was just for spinning and carding and did not necessitate any heavy machinery, but in order to prepare these goods properly it was necessary to have them dyed. There being no dyers in Philadelphia equal to the task, Samuel Wetherill was obliged to undertake this branch of the business also. His house on South Alley is described as being of two frames, which I suppose means what we would call a double house, and he was probably able to turn one frame into a factory and let his family live in the other. However that may be, a little inconvenience more or less in those days did not matter, where all were working together for the common good and for the highest principles. $* * * *$ So it was that Samuel Wetherill, who started as a carpenter, became a weaver, then chemist, etc., and when the war broke out he did 